\title{
Strategies for Spatial and Economic Development
}

\author{
Rupert Rhodd*1, Sandra Schrouder ${ }^{2}$ and Jerry Kolo ${ }^{3}$ \\ ${ }^{1}$ Department of Economics, Florida Atlantic University, USA \\ ${ }^{2}$ Department of Public Administration, Barry University, USA \\ ${ }^{3}$ Depatment of Urban and Regional Planning, American University of Sharjah, Arab Emirates
}

Submission: May 30, 2018; Published: June 08, 2018

"Corresponding author: Rupert Rhodd, Department of Economics, Florida Atlantic University, USA, Tel: 561-297-2545; Email: rhodd@fau.edu

\section{Opinion}

The physical, economic and social distress in inner cities across the nation raises some questions about the efficacy of local development policies and programs. Property-and-lifethreatening conditions in the inner cities tend to have very negative effects on the quality of life of residents. The conditions in their communities often have implications that are economic (disinvestment, unemployment, higher fees to pay for urban services) physical (aesthetic blight), social (crime and insecurity) and political (stereotype and neglect by mainstream).

Among the tools by which government has responded to conditions in inner cities is redevelopment, also used interchangeably with renewal, revitalization and regeneration. Redevelopment is defined narrowly in the literature as a spatially-biased tool, a locally policy decision that focuses on older developed areas that are redeveloped for new use which at the same time removes unwanted activities or people. Through redevelopment policy and programs, city governments allocate tax dollars to seed inner city redevelopment. Today, redevelopment is gauged narrowly as effective only if the targeted areas enjoy a boon in property values, corporate headquarters locations, and mixed-use projects.

As grandiose as some redevelopment projects may seem, they rarely get to the root causes of the problems that plague inner cities. In some cases, redevelopment projects exacerbate (and even cause) the physical and economic differences and imbalances between target and mainstream areas. Redevelopment is based on the physical deterministic principle that the physical environment is preponderant to the social and political environment in dictating how people live in their communities. Hence, redevelopment projects are often designed to enhance, invigorate, conserve, rehabilitate and/or gentrify a depressed and blighted area.

What is missing in most 'classical' redevelopment plans? We contend that what is missing is activities or programs that aim at capacity-building. To undertake redevelopment from the narrow spectrum of replacing slum conditions with better housing, therefore, is to belittle the capacity of people to see and address their conditions holistically.

\section{Strategies}

Here are some suggestions that could lead to more effective redevelopment efforts:

a) On-site delivery of business training in inner cities, preferably by culturally-sensitive professionals and experts at rates that are affordable. This will go a long way to boost the productivity and effectiveness of existing businesses, create employment and income generating opportunities, and contribute more to the urban tax base.

b) The provision of business assistance centres where inner city businesses can access information, capital and training at little or no cost to the businesses. For sustained development to occur, the business atmosphere in inner cities needs unsophisticated but progressive approaches to economic development, and these could be provided through business assistance centres.

c) Redevelopment in inner cities requires the involvement of local or community development corporations with power and adequate financial resources to cause or leverage change in the communities. These are grassroots or communitybased agencies with high potentials for strong functional and financial ties with the public and corporate sectors, while maintaining decision-making autonomy in the community.

d) Often, the resources controlled by individual entrepreneurs interested in investing in inner cities are too meagre to address the problems of development in these communities. This is where community joint ventures can boost economic development efforts. Joint ventures have become the most popular approach to most redevelopment activities in the public and private sectors. This cooperation will give the public and corporate sectors the confidence and interest to support redevelopment in inner cities. Furthermore, intra-community joint ventures could lead to the formation of investment groups that are often missing in inner cities.

e) Parallel to joint ventures are reciprocal credit groups, a concept and practice that has proven to be effective in providing modest, risk-free business start-up funding to 
a large number of communities in Third World countries, where conventional bank credits are non-existent or extremely hard to come by. This program works through a pool of funds put together by a group of mutually trusting and cooperative people. Each member of the group then takes turn in drawing an equal amount of money from the pool until everyone has had a turn. After that round, the group may decide to terminate the credit group or begin a second round of contributions and withdrawals. This arrangement is quite adequate in providing very small, interest free and risk-free cash for emergency use, business start-up or expansion, and other uses. This form of capitalization has worked effectively in the Third World due to some commonality of values and other strong bonds, mainly familial, among group members. In parts of the developed world, this practice is partly at the heart of the sharing or circular economy, and what is termed "commonomics".

f) The incentives and attractions for businesses to grow or expand in inner cities must come from both government and individual communities; therefore, the creation of a business promotion zone by the government is necessary. With a business promotion zone, governments must invest in public works as a prerequisite to economic and human resource development, and inner cities must organize aggressive, enlightened and/or powerful community-based groups that can "get things done." These groups should seek to mobilize people to clean up communities periodically, organize community rallies against crime, solicit public and private funds to beautify the community, lobby investors and entrepreneurs to locate in inner cities, work out agreements with public and private service providers to serve inner cities, and so on. These groups are supposed to be community ambassadors to the corporate sector, as well as community facilitators in addressing local problems.

g) In the current post-industrial economy, information holds the key to successful transaction. Think Tanks are one of the various tools for information generation, analysis and transmission, using acceptable methods and modern technology. The role of Think-Tanks is to aid effective development by critically analyzing and furnishing up-todate and reliable data for planning purposes. Think Tanks can enrich the data base by which inner city businesses can understand, and take advantage of, the gamut of public policies and laws, and/or public-private business financing and assistance programs.

\section{Conclusion}

The traditional "clear-relocate-build" redevelopment approach seems to have failed in America's inner cities. Hence, innovative programs that are small, feasible, and practical need to be tried. These programs should integrate the economic, environmental, political and social elements of redevelopment in a progressive rather than disjointed fashion. With this integrative approach, the goal of redevelopment should be the kind of selfreliance that unlocks the doors of economic, political and social participation for inner city residents. Economic development, which is the focus of this opinion paper, should be understood as a process that increases the adaptive capacity of an economic system or subsystem. The interactions of human resources with the other factors of production should be the basis for sustained economic development.

\begin{tabular}{l} 
Your next submission with Juniper Publishers \\
will reach you the below assets \\
- Quality Editorial service \\
- Swift Peer Review \\
- Reprints availability \\
- E-prints Service \\
- Manuscript Podcast for convenient understanding \\
- Global attainment for your research \\
- Manuscript accessibility in different formats \\
( Pdf, E-pub, Full Text, Audio) \\
- Unceasing customer service \\
Track the below URL for one-step submission \\
https://juniperpublishers.com/online-submission.php \\
\hline
\end{tabular}

